(C) 2019 Soroko, Mykhailenko. This article is distributed under the terms of CC Attribution-Share Alike 4.0 International as described at https://creativecommons.org/lice-nses/by-sa/4.0

UDC: $373.3 / .5 .011 .3-051: 005.336 .2]: 004.5 / .9$

\title{
TEACHERS' DIGITAL COMPETENCE DEVELOPMENT AS AN IMPORTANT FACTOR FOR THE CREATION AND SUPPORT OF THE STEAM-BASED EDUCATIONAL ENVIRONMENT
}

\author{
Nataliia Soroko \\ PhD in Education, postdoctoral student, \\ Institute of Information Technologies and Learning Tools \\ of NAES of Ukraine, Kyiv, Ukraine \\ https://orcid.org/0000-0002-9189-6564; e-mail: nvsoroko@gmail.com \\ Lorena Mykhailenko \\ PhD in Education, Associate Professor \\ Shupyk National Medical Academy of Postgraduate Education, Kyiv, Ukraine \\ https://orcid.org/0000-0002-9867-7495; e-mail: la-mykhailenko@rambler.ru
}

The article is focused on studying teachers' digital competence as a significant factor for the creation and support of the STEAM-based educational environment. The purpose of the article is to analyze teachers' experience in using information and communication technology (ICT) for the STEAM-education support in secondary schools and highlight the main problems which may arise during this process. This research explores the following questions: What is the role of the teachers' digital competence in creating and supporting the STEAM-based educational environment? What are the ways to solve the problem of insufficient teachers' digital competence for creating and supporting the STEAM-based educational environment?

The teachers' digital competence development is viewed as the most important for creating and supporting the STEAM-based educational environment in schools.

The main ways to solve the problem of teachers' insufficient digital competence for creating and supporting the STEAM-based educational environment are as follows: creating ICTs courses for teachers to support STEAM-education and cooperative learning and teaching activities in schools; organizing centers, courses, conferences, trainings, webinars, etc. on STEAM-education for teachers who will coordinate international and national projects; monitoring students' skills in STEMeducation; engaging teachers, students of general education schools and institutions of informal learning, scientists and researchers, etc. to develop the virtual STEAMbased educational environment. 
Creating the STEAM-based educational environment in general education schools and other educational institutions is a research perspective, which will contribute to developing the teachers' digital competence in using ICT in STEAMeducation.

Key words: information and communication technologies, teachers' digital competence, secondary school, STEAM-based educational environment, STEAMeducation.

Стаття присвячена проблемі розвитку ијиррової компетентності ВчителіВ для створення та підтримки STEAM-орієнтованого осВітнього середовища. Досліджено досвід викладачів з вирішення основних питань впровадження STEAM-орієнтованого підходу на всіх ріВнях осВіти з використанням інформаційно-комунікаційних технологій. Метою статті є проаналізувати досвід вчителів у використанні IКТ для підтримки STEAM-освіти в загальноосвітніх школах і виділити основні проблеми, що можуть виникнути під час иъого проиесу.

Розъиток изифрової компетентності вчителів був визнаний найважлиВішим для створення та підтримки STЕАМ-оріснтованого осВітнъого середовища у закладах загальної освіти. Основними шляхами вирішення проблеми розвитку циифрової компетентності вчителя для створення та підтримки STEAM-орієнтованого осВітнъого середовища Визначено такі: створення курсіВ з використання IКТ для вчителів щодо підтримки STЕАM-осВіти, спільного навчання та Викладацької діяльності $в$ иколах; організація конферениій, тренінгів, вебінарів та інших заходів із рішення проблем STEAM-освіму для вчителів, створення центрів, що будуть координувати міжнародні та національні проекти; моніторинг навичок студентіВ щодо STЕМ-осВіти; залучення студентів, викладачів, учнів загальноосвітніх шкіл та позашкільних навчальних закладів, студентів вищих навчальних закладів, науковиів і дослідників для розробки Віртуального осВітнъого середовища STEAM.

Перспективами подальиих досліджень є проектування STEAM-орієнтоВаного осВітнъого середовища у загальному освітнъому закладі, яке сприятиме розвитку иифрової компетентності вичтелів.

Ключові слова: інформаційно-комунікаційні технологій, изифрова компетентність виителя, загальноосВітня икола, STЕАМ-орієнтоване осВітнє середовище, STEAM-осВіта.

Introduction. The rapid development of the information society requires competitive young people, who can demonstrate their knowledge, skills and abilities in the research field, can solve various professional problems and are able to use ICT. This can be implemented through the STEAM-based educational approach, which provides synergy of science, technology, engineering, art, mathematics and the use of modern information and communication technologies in teaching and learning. STEAM-based education is important and relevant for students due to the fact that it is one of the approaches that can help them understand the world, create a world in 
the form of comprehensive innovation and develop the innovative ability to solve problems (American Association for the Advancement of Science, 1993; Assessment and Teaching of 21st Century Skills (ATC21S) project, 2009).

This leads to the search for special ways of developing teachers' professional competences, in particular digital competence, which may have a positive impact on the formation of the students' skills in accordance with the ever-increasing requirements. One of these ways, in our opinion, is the creation of the STEAM-based educational environment that should facilitate the implementation of practical, interdisciplinary, and project approaches in teaching students such subjects as Science, Technology, Engineering, and Mathematics (STEM) through the formation of creative thinking and the use of the various arts (for example, design, literature, architecture, etc.) in the educational process (Yakman, G., 2008).

The article's aim is to substantiate teachers' experience of using ICTs for the STEAM-education support in secondary schools and highlight the main problems that may arise during this process and also the ways to solve them.

This research is aimed at answering the following questions:

What is the role of the teachers' digital competence in creating and supporting the STEAM-based educational environment?

$>$ What are the ways to solve the problem of insufficient teacher's digital competence for creating and supporting the STEAM-based educational environment?

The problems of STEM-education (S - Sciences, T - technological sciences, E engineering, and $\mathrm{M}$ - mathematics) implementation in a general education school were considered by such scientists as Bromirs'ka, A. M., Kolomiyecz, D. I. (2017) (Bromirska, A. M., Kolomiiets, D. I., 2015), Debry, M. and Dr. Agueda Gras-Velazquez (Maïté Debry, and Dr. Agueda Gras-Velazquez, 2016), Jacina Leong (Jacina Leong, 2017), Heidi Sublette (Sublette, H., 2013), Nikirk, M. (Nikirk, M., 2012), etc.

The STEAM-approach in the STEM-based education is defined as:

- training in which each subject is taught separately, with the teachers' expectations that the students will be using the synthesis of disciplinary knowledge (American Association for the Advancement of Science (AAAS, 1993) (American Association for the Advancement of Science, 1993), etc;

- systematic and institutionalized training in the fields of science, technology, engineering and mathematics at all levels of student education, and also, it is a study of disciplines and professions in a wide range, including agriculture, physics, psychology, medical technology and automotive engineering (Ashby, M., 2006);

- integrative education (Sanders, M., 2006; Wells, J. G., 2006);

- a transdisciplinary pedagogical approach through which students are given the opportunity, by using the project method, to be independent in solving the problems that may arise while fulfilling the learning tasks set by the teacher, who carries out the role of a facilitator (Heidi Sublette, 2013).

The arguments that the Arts («A») and creative approaches must be contributing to the effectiveness of STEM-education (STEAM) were considered and analyzed by L. Bergonzi and J. Smith (L. Bergonzi and J. Smith, 1996), J. Tarnof (J. Tarnof, 2011), D. A. Sousa and T. Pilecki (D. A. Sousa and T. Pilecki, 2013), E. Kim, S. Kim, 
D. Nam and T. Lee (E. Kim, S. Kim, D. Nam and T. Lee, 2012), D. F. Keefe and D. H. Laidlaw (D. F. Keefe and D. H. Laidlaw, 2013), etc.

According to the researchers, the following Arts subjects for the STEM-based approach should be introduced in schools:

- the humanities, the subject of which are certain manifestations of human spirituality, philology, ethics, philosophy, history, aesthetics, etc. (A. M. Bromirs'ka, D. I. Kolomiiets, 2017; D. Ferraro, 2007);

- industrial design, architecture and industrial aesthetics (A. M. Bromirs`ka, D. I. Kolomiiets, 2017; Yu. M. Babchuk, O. O. Biryuk, 2017; A. V. Frolov, 2010);

- writing, rhetoric, literature, theatrical art, dance, painting, musical art (D. A. Sousa, \& T. Pilecki, 2013; Jacina Leong, 2017);

- visual arts, music, dance/movement, imagery, theater, literature, play or humor or any activity relating to such subjects and «arts consumption» (attending, listening to, watching, or reading) (Bergonzi \& Smith, 1996; Mark E. Rabalais, 2014).

According to the American Association for the Advancement of Science Report (American Association for the Advancement of Science, 1993):

«The ideas and practice of science, mathematics, and technology are so closely intertwined that we do not see how education in any one of them can be undertaken well in isolation from the others.»

We created a questionnaire for defining STEAM-education and determining teachers' attitude to this approach, taking into account the studies of the British Educational Research Association (BERA) (L.»Colucci-Gray, Prof. P. Burnard, Ms. Ca. Cooke, Dr. R. Davies, Dr. D. Gray, Ms. J. Trowsdale, 2016), and information materials from the Site «EdCloset» (https://educationcloset.com/steam/what-issteam/). To clarify the basic concepts of «STEAM-education» and «STEAM-based educational environment», this questionnaire includes such important questions as:

$>$ What is STEAM-education?

$>$ What is the most important way of teaching STEAM-education?

$>$ What are the most important computing-based tools for creating and supporting the STEAM-based educational environment?

A total of 127 teachers (from secondary schools in Ukraine) took part in this survey. Learning environment was another issue $\mathrm{n}$ the questionnaire as presented in Table 1. By using a five Likert scale ranging from very undesirable (1) to very desirable (5), the participants were asked which learning environment they would prefer for STEAM courses.

Table 1

The survey results about teachers' knowledge of STEAM-education

\section{STEAM-education is:}

- an educational approach to learning that uses Science, Technology, Engineering, the Arts and Mathematics as access points for guiding student inquiry, dialogue, and critical thinking. The end results are students, who take thoughtful risks, engage in experiential learning, persist in problemsolving, embrace collaboration, and work through the creative process
Mean values 
Continuation of table 1

- the study, in which each subject is taught separately with the teachers' hope that students will apply synthesis of disciplinary knowledge

- used to indicate ways in which the Arts or art-practices (and sometimes more broadly the Humanities and Social sciences) engage with the STEM subjects of Science, Technology, Engineering and Mathematics

- a subject which includes Science, Technology, Engineering, the Arts and Mathematics for teaching students to solve different problems

- I do not know how to use this method

Total $(\mathrm{N}=127)$

The teachers' answers to questions «What is STEAM-education?» showed that the majority of them consider the definition "STEAM is an educational approach to learning that uses Science, Technology, Engineering, the Arts and Mathematics as access points for guiding student inquiry, dialogue, and critical thinking. The teachers are positive about the STEAM- approach and they are ready to use it in the classroom.

The mean values in Table 2 indicate the ways of teaching STEAM-education the teachers would prefer. This question if it is necessary to create the STEAM-based educational environment for implementation the STEAM-approach in secondary school is important for us to highlight.

Table 2

The survey results about teachers' attitudes to the ways of teaching STEAM-education

\begin{tabular}{l|c}
\hline \multicolumn{1}{c|}{ The most important way of teaching STEAM-education is: } & $\begin{array}{c}\text { Mean } \\
\text { values }\end{array}$ \\
\hline - to encourage interactions between formal and informal learning & 4.81 \\
\hline $\begin{array}{l}\text { - to encourage interactions between formal and informal learning, and } \\
\text { the STEAM-based online educational environment }\end{array}$ & 4.5 \\
\hline - SMART school & 3.76 \\
\hline - Virtual learning & 2.65 \\
\hline - Distance learning & 2.87 \\
\hline - Online learning & 3.76 \\
\hline Total $(\mathrm{N}=127)$ & \\
\hline
\end{tabular}

The mean values in Table 2 indicate that teachers prefer to encourage interactions between formal and informal learning but they do not understand how to use ICT for supporting STEAM-education («SMART school»: 5 teachers have chosen «5» $(4 \%)$; 86 teachers have chosen «4» $(68 \%)$; 36 teachers have chosen «3» $(28 \%)$; «Online learning»: 5 teachers have chosen «5» $(4 \%)$; 86 teachers have chosen «4» (68\%); 36 teachers have chosen «3» $(28 \%))$. Teachers' answers to the question «What is the most important way of teaching STEAM-education?» show that teachers are interested in creating the STEAM-based online educational environment. 
The mean values in Table 3 indicate which computing-based tools are most important for creating and supporting the STEAM-based educational environment.

The survey results about teachers' attitudes to the most relevant computing-based tools for creating and supporting

the STEAM-based educational environment

\begin{tabular}{l|c}
\hline $\begin{array}{l}\text { The most important computing-based tools for creating and } \\
\text { supporting the STEAM-based educational environment are: }\end{array}$ & $\begin{array}{c}\text { Mean } \\
\text { values }\end{array}$ \\
\hline$>$ Google Drive & 4.9 \\
\hline$>$ LinoIt & 2.55 \\
\hline$>$ Padlet & 4.9 \\
\hline$>$ Thinglink & 2.7 \\
\hline$>$ Todaysmeet & 2.7 \\
\hline$>$ Kahoot! & 4.5 \\
\hline$>$ Quizizz & 2.5 \\
\hline$>$ Surveyanyplace & 2.3 \\
\hline$>$ Moodle & 3.7 \\
\hline$>$ Scratch & 4.5 \\
\hline$>$ I don't know how to use the computing-based tools for creating & - \\
\hline and supporting the STEAM-based educational environment & - \\
\hline Suggest tools & \\
\hline Total (N=127) & \\
\hline
\end{tabular}

Table 3 demonstrates that teachers can use computing-based tools for creating and supporting the STEAM-based educational environment, but it is highly important to develop their digital competence.

The mean values in Table 4 indicate what teachers' skills are important for implementing the STEAM-approach in secondary school and to create the STEAMbased educational environment.

Table 4

The survey results about teachers' attitudes to the most relevant skills for creating and supporting the STEAM-based educational environment

\begin{tabular}{l|c}
\hline $\begin{array}{c}\text { The most important skills for creating and supporting the STEAM- } \\
\text { based educational environment are in the use of: }\end{array}$ & $\begin{array}{c}\text { Mean } \\
\text { values }\end{array}$ \\
\hline - online tools to create and manage training projects & 4.9 \\
\hline - openeducational resources & 4.9 \\
\hline - online tools for conducting seminar, forums and others & 4.9 \\
\hline - programming languages & 2.7 \\
\hline - online security tools & 3.7 \\
\hline - online games & 3.5 \\
\hline - online tools for creating tests and quizzes & 4.5 \\
\hline Total $(\mathrm{N}=127)$ & \\
\hline
\end{tabular}


Table 4 demonstrates that teachers need to develop such skills as using online tools to create and manage training projects; open educational resources; online tools for conducting seminar, forums and more; online security tools; online tools for creating tests and quizzes; online games.

As shown in Tables 1, 2, 3, 4, the participants are mostly in need of knowledge and skills to use ICT. STEAM-education is the educational approach, in which each subject is taught separately with the hope that students will apply the synthesis of disciplinary knowledge. G. Yakman points out that using the STEAM-based environment in school teaching is the way of motivating students to participate in educational projects related to the application of science, technology, engineering, art and mathematics (Yakman, G., 2008).

According to the research of the British Educational Research Association (BERA, 2016) it is highly important to include the «A» in STEM-education: «Firstly, there are arguments that the arts and creative approaches will contribute to the effectiveness of STEM-education. Secondly, that the inclusion of the arts emphasizes the possibility of multi and trans-disciplinary practices, reflecting long-held, historical, social, and educational views of the arts and sciences as naturally connected. Thirdly, it identifies the value of the arts in promoting an engagement with «the human condition», the values we collectively espouse, and the productive exploration of controversial issues. Thus, it is argued, the arts offer diverse and engaging modes for individuals and societies to approach, articulate and process experience» (Reviewing the potential and challenges of developing STEAM education through creative pedagogies for 21st learning: how can school curricula be broadened towards a more responsive, dynamic, and inclusive form of education?, 2017).

Thus, the STEAM-based educational environment has an impact on the development of skills in the fields of natural sciences, technology, mathematics, students creative critical thinking, solving practical research issues through the synergy of STEAM disciplines and the use of ICT. The STEAM-based educational environment is an educational environment, in which ICT create learning and teaching conditions in synergy with the natural sciences, technology, engineering, arts, mathematics, teamwork, cooperative work of teachers and students for the effective achievement of teaching goals, and comprehensive personality development. M. Nikirk recommends a number of strategies for the effective implementation of the STEM-based approach in secondary schools (Nikirk, M., 2012). They are as follows:

- demonstrating graphs at the beginning of setting tasks, etc., since visualization facilitates faster perception of the material than just reading a text;

- beginning with an explanation of the purpose, which should be objective;

- providing students with accurate and abstract concepts to be realized using examples from real life, the students should understand the connection with abstract concepts;

- using ICT for interactive learning process, for searching and presenting educational resources; creating and using virtual laboratories, online games, software, blogs, etc.; approach;

- focusing not on the teacher-centered approach, but on the student-centered 
- teaching the business conduct and etiquette that meets the needs of business and entrepreneurship; presenting data with charts and graphs by using graphical editors and presentations;

- focusing not on the group-work, but on the team-work;

- promoting the development of an educational environment, in which the core values are students' creative and independent thinking;

- engaging students in the interactive learning activity; teaching them to be efficient at evaluating and using technologies, including ICT, for learning and selfeducation;

- using the "peer-to-peer» method, that is to engage students as teachers, project leaders, problem solvers, which should build their leadership skills.

M. Nikirk focuses on the main role of teachers' digital competence for creating and supporting the STEM-based educational environment (Nikirk, M., 2012).

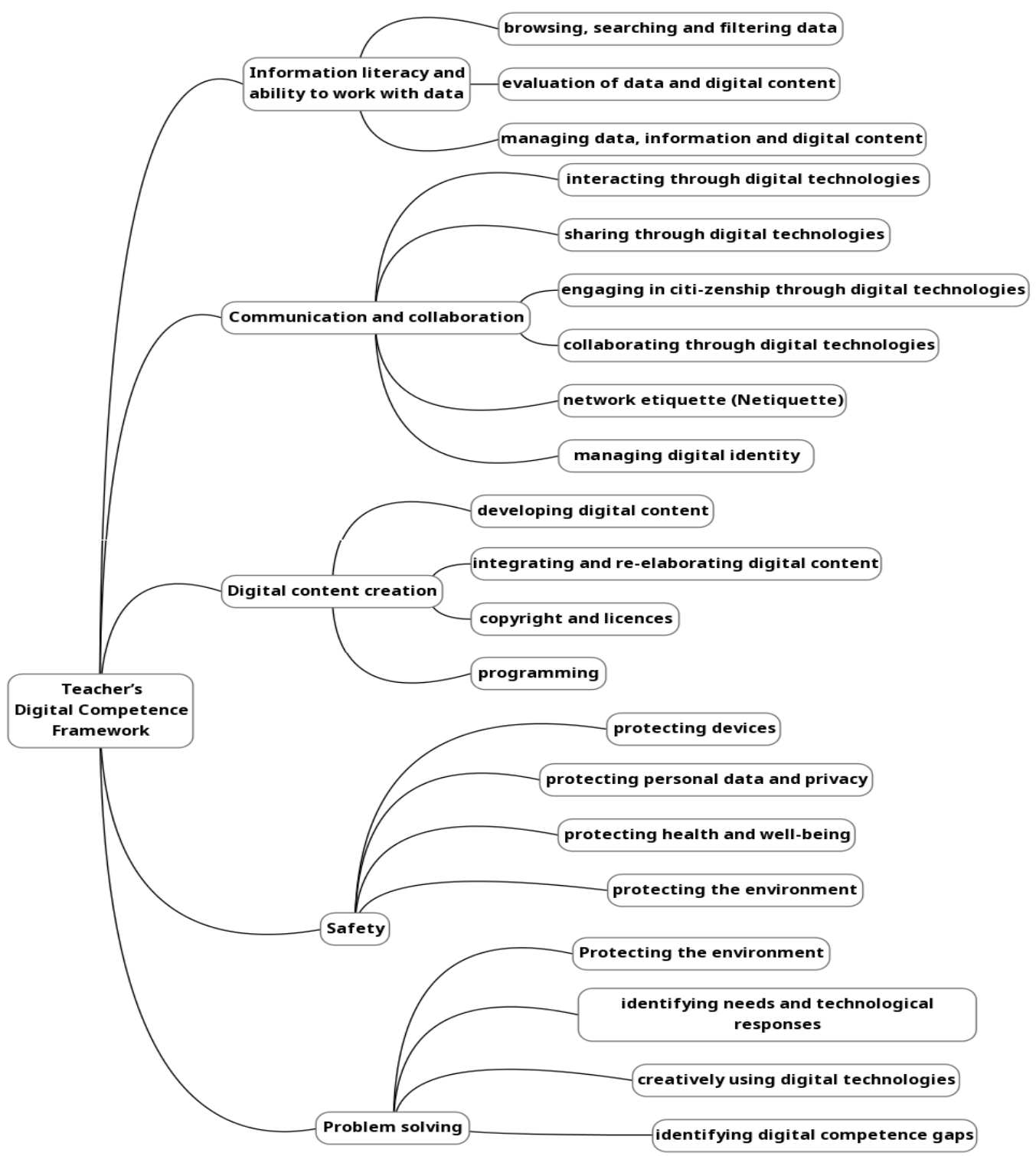

Figure1. The Digital Competence Framework for the teachers' digital competence according to the Digital Competence Framework for Citizens

(Carretero, S.; Vuorikari, R. and Punie, Y., 2017, DigComp 2.1) 
According to the Digital Competence Framework for Citizens (DigComp 2.1) (Carretero, S., Vuorikari, R., and Punie, Y., 2017), the teachers' digital competence includes such skills (Fig. 1) as: information literacy and ability to work with databases (browsing, searching and filtering data, evaluation of data and digital content, managing data, information and digital content); communication and collaboration skills (interacting through digital technologies, sharing through digital technologies, engaging in citizenship through digital technologies, collaborating through digital technologies, network etiquette); digital content creation skills (developing digital content, integrating and re-elaborating digital content, copyright and licenses, programming); skills of safe use of the Internet network (protecting devices, protecting personal data and privacy, protecting health and well-being, protecting the environment); problem solving skills with ICT (protecting the environment, identifying needs and technological responses, creatively using digital technologies, identifying digital competence gaps).

In our opinion, the teachers' digital competence is the ability to autonomously and responsibly carry out professional and pedagogical tasks in a particular subject area or to meet individual needs and solve socially significant problems with the help of ICT.

Taking into account the analyzed scientific literature, we have identified the main problems of the teachers' digital competence development for creating and supporting the STEAM-based education environment in schools.

Table 5

The main problems of teachers' digital competence development for creating and supporting the STEAM-based education environment in schools

\begin{tabular}{l|l}
\hline $\begin{array}{l}\text { Problems of teachers' digital } \\
\text { competence development for } \\
\text { creating and supporting the } \\
\begin{array}{c}\text { STEAM-based educational } \\
\text { environment in schools }\end{array}\end{array}$ & \multicolumn{1}{|c}{ Problem solutions } \\
\hline $\begin{array}{l}\text { Teachers are not ready to use } \\
\text { ICT for the STEAM-based } \\
\text { education support in the } \\
\text { classroom }\end{array}$ & $\begin{array}{l}\text { Creating courses (MOOC) for teachers on using ICT } \\
\text { to support STEAM-education, cooperative learning } \\
\text { and teaching activity in schools (Assessment and } \\
\text { Teaching of 21st Century Skills (ATC21S) project, }\end{array}$ \\
\hline $\begin{array}{l}\text { Insufficiet management and } \\
\text { policy for the STEAM-edu- } \\
\text { cation support, and the }\end{array}$ & $\begin{array}{l}\text { Organizing centers, courses, conferences, trainings, } \\
\text { STEAM-based educational } \\
\text { webinars, etc. on the STEAM-education support for } \\
\text { environment }\end{array}$ \\
$\begin{array}{l}\text { teachers, which must coordinate international and na- } \\
\text { tional projects; monitoring students' skills in STEM- } \\
\text { education (Assessment and Teaching of 21st Century }\end{array}$ \\
$\begin{array}{l}\text { Skills (ATC21S) project, 2009; M. Nikirk, 2012; } \\
\text { M. Debry and Dr. Agueda Gras-Velazquez, 2016; } \\
\text { K. C. Koutsopoulos , 2015) }\end{array}$ \\
\hline
\end{tabular}


Insufficiet development of the online STEAM-based educational environments
Engaging teachers, high school students and out-ofschool educational institutions, scientists and researchers, etc. to develop the virtual STEAM-based educational environment (Assessment and Teaching of 21st Century Skills (ATC21S) project, 2009; M. Nikirk, 2012; M. Debry and Dr. Agueda Gras-Velazquez, 2016; K. C. Koutsopoulos, 2015; Md. Mokter Hossain, Michael G. Robinson, 2012)

Low students motivation to study the STEAM disciplines and teachers' motivation to use ICTs for the STEAMbased education support in the classroom are not sufficiently carried out
Promoting «organizing fundraising events with the community or other projects that increase budgeting and develop math skills; teaching the youth sciences at summer camps or after-school programs; getting students to join the math and science clubs; encouraging technological hobbies among school children; helping them participate in science fairs; basic computing and internet browsing; including them in Internet forums and social networking; giving them books and magazines on science and mathematics; motivating them to pursue science and engineering careers; and helping them learn about computing...» (Md. Mokter Hossain, Michael G. Robinson, 2012)

To implement the set goals of the teachers' digital competence development for creating and supporting the STEAM-based educational environment, the school STEAM-oriented digital environment should be designed and necessary teachers skills for creating and supporting such environment should be determined. The design of the STEAM-based educational environment for secondary school should include the following main steps: setting the goal of creating an environment, which is consistent with the result of teaching and learning in it by its users, such as, for example, the development of students research competence within the STEAM approach of teaching, the development of professional competences of teachers, etc.; analyzing needs of students and teachers in the main elements of the digital environment, such as the necessary ICTs, current topics in the field of STEAM, the necessary forms and methods of teaching and learning, etc.; identifying the essential elements of the environment necessary for creating the school STEAM-oriented digital environment (ICT, current topics in the field of STEAM, the necessary forms and methods of teaching and learning); searching for partners, consultants, sponsors; planning of work with environmental users, for example, conferences, seminars, training projects, competitions, educational exhibitions, etc.; creating a system for distributing news to users of the environment (Jacina Leong, 2017); Kim, E., Kim, S., Nam, D., \& Lee, T., 2012; Land, M. H., 2013; Mark E. Rabalais, 2014; Reviewing the potential and challenges of developing STEAM education through creative pedagogies for 21st learning: how can school curricula be broadened towards a more responsive, dynamic, and inclusive form of education?, 2017; Tarnoff, J., 2011; Yakman, G., 2008). 
Conclusions. The STEAM-education is a highly important approach for developing and reforming education, due to the increasing demand for specialists in the STEM fields in the global labor market.

The STEAM-based educational environment is the environment that combines the functions of computer-oriented, mobile-oriented, cloud-based learning environments, provides the support for learning through practical, focused, interdisciplinary and project approaches which allow students to study subjects of the natural and mathematical cycle and robotics, forming their creative thinking by the use of various arts in the educational process. It contributes to the development of teachers' digital competence, to the students' motivation in studying specified disciplines, solving various problems of sciences, and to effective cooperation between participants of educational process in general education schools on the national and international levels. The main ways to solve the problem of insufficient teachers' digital competence for creating and supporting the STEAM-based educational environment are as following: creating courses (MOOC) for teachers using ICT for STEAM-education, cooperative learning, teaching activity in schools; organizing centers, courses, conferences, trainings, webinars, etc. on the STEAM-education support for teachers, which must coordinate international and national projects; monitoring students' skills in STEM-education; engaging teachers, students of general education schools and outof-school educational institutions, scientists and researchers, etc. to develop the virtual STEAM-based educational environment. Designing the STEAM-based educational environment in general education schools is a research perspective for encouraging the use of ICT and STEAM training in general educational institutions, which will have a positive impact on the teacher's digital competence development.

\section{References:}

American Association for the Advancement of Science (1993). Benchmarks for science literacy: A Project 2061 report, New York: Oxford University Press. Retrieved from: http://www.sciepub.com/ reference/202199.

Ashby, M. (2006). Higher Education: Science, Technology, Engineering, and Mathematics trends and the role of federal programs (Testimony before the committee on education and the workforce, House of Representatives). Washington, D.C.: United States Government Accountability Office. 1-12.

Assessment and Teaching of 21st Century Skills (ATC21S) project (2009). Retrieved from: https:// www.cisco.com/c/dam/en_us/about/citizenship/socio-economic/docs/ATC21S_Exec_Sum ma ry.pdf.

Bergonzi, L., \& Smith, J. (1996). Effects of arts education on participation in the arts. Santa Ana, CA: National Endowment for the Arts. Retrieved from: https://www.researchgate.net/ publication/252625711_Effects_of_Arts_Education_on_Participation_in_the_Arts.

Bromirska, A. M., Kolomiiets, D. I. (2017) Suchasni informatsiini tekhnolohii ta innovatsiini metodyky navchannia $\mathrm{u}$ pidhotovtsi fakhivtsiv: metodolohiia, teoriia, dosvid, problemy. [Modern information technologies and innovative methods of training in the training of specialists: methodology, theory, experience, problems]. Zbirnyk naukovyh prats, Vypusk 49, 19-22.

Carretero, S., Vuorikari, R., and Punie, Y. (2017). DigComp 2.1: The Digital Competence Framework for Citizens with eight proficiency levels and examples of use. Publications Office of the European Union EUR 28558 EN. Doi:10.2760/38842.

Ferraro, D. (2007). W(h)ither liberal education? A modest defense of humanistic schooling in the twenty-first century. In Finn, C., \& Ravitch, D. (Eds.), Beyond the basics: Achieving a liberal education for all children. Washington, D.C.: Thomas B. Fordham Foundation. 25-41. 
Frolov, A. V. (2010). The role of STEM-education in the «new» US economy. Questions of the new economy. № 4, 80-91.

Jacina Leong (2017). «When You Can't Envision, You Can't Give Permission»: Learning and Teaching Through A STEAM Network. Submitted in fulfillment of the requirement for the degree of Master of Arts (Research). Creative Industries Faculty Queensland University of Technology. 140.

Keefe, D. F., \& Laidlaw, D. H. (2013). Virtual reality data visualization for team-based STEAM education: Tools, methods, and lessons learned. In R. Schumaker (Series Ed.) Lecture Notes in Computer Science: Virtual, augmented and mixed reality systems and applications, 179-187. Doi: 10.1007/978-3-642-394 20-1_20.

Kim, E., Kim, S., Nam, D., \& Lee, T. (2012). Development of STEAM program Math centered for Middle School Students. Retrieved from: http://www.steamedu.com/wp-content/uploads/2014/12/ Development-of-STEAM-Korea-middle-school-math.pdf.

Kolomiiets, D. I., Babchuk, Yu. M., Biriuk, O. O. (2017). STEAM-proekty na urokah trudovoho navchaniia Suchasni informacijni texnologiyi ta innovacijni metodyky navchanniia u pidgotovci fahivciv: metodo-logiya, teoriya, dosvid, problemy [STEAM projects during the art and crafts lessons]. Vistnyk. Vypusk 49, 28-31.

Koutsopoulos, K. C. (2015). School on the Cloud: Connecting for Digital Citizenship. European Commission: Lifelong Learning Program - ICT Key Action European Project. 126. Retrieved from: http://www.school onthecloud.net/outputs04.

Land, M. H. (2013). Full STEAM ahead: The benefits of integrating the arts into STEM, Procedia Computer Science, 20, 547-552.

Madden, M. E., Baxter, M., Beauchamp, H., Bouchard, K., Habermas, D., Huff, M., Plague, G. (2013). Rethinking STEM education: An interdisciplinary STEAM curriculum. Procedia Computer Science, 20, 541-546.

Mark E. Rabalais (2014). STEAM: A National Study of the Integration of the Arts Into STEM Instruction and its Impact on Student Achievement. A Dissertation Presented to the Graduate Faculty of the University of Louisiana Lafayette In Partial Fulfillment of the Requirements for the Degree Doctor of Education. 89, 19.

Maïté Debry, and Dr. Agueda Gras-Velazquez (2016). ICT Tools for STEM teaching and learning. Transformation Framework. Retrieved from: http://www.stemalliance.eu/documents/99712/ 104016/STEM_A_and_MS_ICT_Tools_in_Edu_paper_v06_Final.pdf/be27b1aa-c4a6-40c5-a7502a11b9f896b6.

Mokter Hossain, Md., Michael G. Robinson (2012). How to Motivate US Students to Pursue STEM (Science, Technology, Engineering and Mathematics) Careers.US-China Education Review, 442451. Retrieved from: https:/ / files.eric.ed.gov/fulltext/ED533548.pdf.

Nikirk, M. (2012). Teaching STEM to millennial students. Tech Directions. 71(7), 13-15. Retrieved from http:/ / www.omagdigital.com/publication/ ?i=98503.

Reviewing the potential and challenges of developing STEAM education through creative pedagogies for 21st learning: how can school curricula be broadened towards a more responsive, dynamic, and inclusive form of education? (2017). Retrieved from: https://jotrowsdale.files.wordpress.com/ 2017/11/beraresearch-commission-report-steam.pdf.

Sousa, D. A., \& Pilecki, T. (2013). From STEM to STEAM: Using brain-compatible strategies to integrate the arts. Retrieved from: http://amazon.com.

Sublette, H. (2013). An effective model of developing teacher leaders in STEM education: Pepperdine University. Retrieved from: https://eric.ed.gov/?id=ED563130.

Tarnoff, J. (2011). STEM to STEAM. Recognizing the Value of Creative Skills in the Competitive. Retrieved from: http://www.huffingtonpost.com/john-tarnoff/stem-to-steam-recognizing_b_ 756519.html.

Yakman, G. (2008). STEAM Education: an overview of creating a model of integrative education. Retrieved from: https://www.researchgate.net/publication/327351326_STEAM_Education_an_overview _of_creating_a_model_of_integrative_education. 